\title{
WHAT DO STUDENTS NEED TO KNOW? HOW ABOUT THE IDEA OF PROGRESS?
}

\author{
David Pickus
}

\begin{abstract}
Abstrak
Mempelajari Arkeologi sangat erat hubungannya dengan mempelajari pemikiran mengenai "progres". Konsep tentang "progres" ini sebuah pemikiran yang popular pada tahun 1920-an, tidak saja berlaku bagi ilmu Arkeologi, tetapi untuk pengertian mengenai perkembangan intelektual masyarakat di dunia. Pemikiran mengenai "progres" adalah salah satu pemikiran fundamental yang berkaitan erat dengan peradaban-peradaban yang dimengerti dalam konteks sejarah. "Apakah pemakaian bahan metal menunjukkan suatu kemajuan?," mengingat bahwa pada zaman Xuanyuan, senjata dibuat dari batu, kemudian batu giok di zaman Huangdi, dan perunggu di zaman Yu. Hal ini menunjukkan bahwa Arkeologi berhubungan dengan pengetahuan kesejarahan dan pranata-pranata sosial, selain mengaplikasikan analisis biokimia pada suatu artefak. Sebagai suatu contoh tentang sebuah penelitian multi disiplin dalam Arkeologi didapat pada hipotesis buku Why the West rules-for now, karya Ian Morris, 2010, yaitu bahwa wilayah Mediterania pada abad pertama mengalami kemajuan ekonomi yang tertinggi dibandingkan dengan wilayah2 lainnya. Kesimpulan ini diperoleh karena menganalisis bekas2 kapal yang tenggelam di lautan Mediterania dan tingkat lapisan timbel di tanah. Pemikiran mengenai "progres" disini adalah penarikan sintesis dari perspektif berbagai ilmu, yang disebut consilience. Dengan demikian, karya masa yang silam dimengerti dalam konteksnya. Begitu pula karya pada masa sekarang tidak mengurangi nilainya atau bertambah nilainya dalam konteks "progres".
\end{abstract}

\section{Kata Kunci}

Progress, consilience.

\begin{abstract}
Studying Archeology needs an understanding of the idea of progress. The concept of progress was popular in the 1920s, and it was not for Archeology alone, but it became a new intellectual understanding of the world. "The idea of progress is one of the fundamental notions grappled by civilizations with a historical sense". "Does this change in the use of metals equal development?," reminds us to the Xuanyuan era where stone was used to make weapon, whereas jade in the time of Huangdi, and bronze in the time of $\mathrm{Yu}$. This shows that Archeology is related to history and some social institutions, besides applying biochemical analysis to an artifact. As an example of a multi disciplinary archeological research was found in the hypothesis of Why the West rules - for now, by Ian Morris, 2010, which states that the Mediterranean region has the most advanced economic achievement compared to the other regions. The conclusion of which was drawn from analysis of shipwrecks in the Mediterranean ocean and the level of lead in the soil. The concept of progress in this case was the implication of a synthesis contributed from the perspective of several disciplines, or consilience. Thus, the artifacts of the past should be interpreted contextually, and so were the present materials. The values of which will have never been lesser or better in the light of progress.
\end{abstract}

\section{Keywords}

Progress, consilience. 
Everyone knows that archeology need to learn the art and science of archeology. But beyond the specifics of the discipline itself, is there any sort of general knowledge that we can say with confidence that all archeology students must learn? On May 24, 2011 I gave a brief talk to University of Indonesia archeology and museum studies students about why, in an age of globalization, what they really needed to gain perspective on their own chosen discipline was an appreciation of the idea of progress. Looking back, I wonder whether I myself "made any progress" with this effort to expand the students' intellectual horizons. But this, it occurred to me, was probably due to a mistake of my own. Students almost never know what they should and shouldn't be taught. That's why they are students. Instead, the audience should be the wider Indonesian intellectual community, not only the faculty of archeology. They are the ones who have a decisive say in what students are taught.

Moreover, concerns about pedagogy always spill over: thinking about what students are learning in one discipline impacts the way we understand another. If, as I intend to argue, archeology students need deliberate training in thinking about the idea of progress, it stands to reason that they are not alone in this need-and that other departments may wish to give their own students a similar training in intellectual history. What follows is an expandedand more documented version of the talk I gave. It aims to make a contribution not only to a discussion of what should be on the curriculum of students, but toward a topic I believe is crucial for the development (or progress) of all nations. This is the question of how to prepare students to think for themselves, even when there is no one there to tell them what to think and how to do it.

Now, can some reflection on the idea of progress really do all that? Putting it this way makes it seem quite improbable particularly since the underlying concept of an "idea of progress" is not typically understood as an up-to-date and progressive one. Globalization and the general upending of established structures receive a great deal of discussion, and whole departments are created to expose students to the "theory" of social change, there is little collective demand that they be exposed to the idea of progress. In fact, in 1961 the distinguished British historian, E. H. Carr, giving a series of lectures at Cambridge University called the idea of progress "old fashioned." If the idea of progress is old fashioned in 1961, why should we return to it fifty years later? Making matters worse is the fact that, for the last several decades, some versions of the idea of progress have not only been considered stuffy or old-fashioned, but politically reactionary and morally harmful. Thus, an author with strong archaeological interest, Ronald Wright, could warn at the start of his An Illustrated History of the Idea of Progress that:

\footnotetext{
1 Carr's comment can be found in the printed version of his lecture, What is History (New York), 1962. A useful overview of the "rise and fall" of the enthusiasm for ideas of progress in intellectual circles can be found in George G. Iggers' "The Idea of Progress: A Critical Reassessment," American Historical Review, Vol. 71, Oct. 1965.
} 
Despite certain events of the twentieth century, most people in the western cultural traditions still believe in the Victorian ideal of progress, a belief succinctly defined by the historian Sidney Pollard in 1968 as 'the assumption that a pattern of change exists in the history of mankind... that it consists in irreversible changes in one direction only, and that this direction is toward improvement." 2

It should be noted at once that Wright does not quote anyone sincerely maintaining that human progress is "irreversible," most probably because this is a caricatured view that almost no one maintains. Indeed, if turn to the Victorian thinkers that ostensibly propounded this naïve idea of progress like, for instance, Herbert Spencer (1820-1903), we see that though he firmly believed in a "law" of progress, his main point was to argue, as he put it, "that in which progress essentially consists, is the transformation of the homogeneous into the heterogeneous." ${ }^{3}$ The meaning of this proposed law can postpone for another time. What needs to be stressed now is that Spencer's "Victorian ideal of progress" was not that simplistic that he thought any change was equivalent to progress, and nothing could hinder it. And even though he, and other believers in progress,can be criticized in any number of ways, it is not true that those who endorse progress simply blind themselves to the facts and refuse to take into account any contradictory evidence. Philosophies of progress are not dispensed with that easily.

Indeed, behind the notion that the belief in progress is nothing more than an overtaken ideology lies a claim that deserves to be questioned in turn. Here is how Ronald Wright puts this common notion:

Our practical faith in progress has ramified and hardened into an ideology - a secular religion which, like the religion that progress has challenged, is blind to certain flaws in its credentials. Progress, therefore, has become "myth" in the anthropological sense. ${ }^{4}$

There is nothing especially new in talking about the idea of progress this way. Some forty years ago in an extensive study of the subject, Good Tidings: The Belief in Progress from Darwin to Marcuse, W Warren Wagar put it this way:

What happened in the intellectual history of Europe between the late fifteenth and the early nineteenth centuries, I suggest, was not only a revival of classical taste, or a revolution in science, but the growth of a distinctively modern religion. It was a religion of the mind, which built no churches and inspired no rites or creeds. Yet it ministered to the same needs as Christianity, and for many intellectuals took the place of Christianity. This new religion was a rational and liberal humanism.

After discussing the origins of this "new religion" in more detail, Wagar concluded:

\footnotetext{
2 Ronald Wright, An Illustrated Short History of Progress, p. 3.

3 Herbert Spencer, "Progess: Its Law and Causes", The Westminster Review, Vol 67 (April 1857), pp 445-447, $451,454-456,464-65$

4 Wright, p. 3.
} 
The rational and liberal humanism of the modern era has always been, at its roots, a religion of man, a faith in man and human possibility, which ultimately evolved into a faith in history, or what amounts to the same thing, a faith in progress. ${ }^{5}$

To be sure, both Wagar and Wright take care to ensure that they are not utterly dismissive of those who adhere to this "myth" or "religion" of progress. Wright says that "The myth of progress has sometimes served us well-those of us seated at the best tables, anyway - and may continue to do so." ${ }^{6}$ Yet he insists that it has "also become dangerous. Progress has an internal logic that can lead beyond reason to catastrophe."7 Undoubtedly, but we should ask if anyone seriously thinks otherwise, even those who believe that humanity should fully endorse the idea of progress. Indeed, the fact than ideas of progress can go "beyond reason" does not mean that they will, and calling those endorse some version of progress adherents of a "religion" or a "myth" simply hinders debate, and deflects our attention from what most matters, namely a clear-sighted understanding of when ideas (and even ideologies) of progress help us and when they, in fact, create the kinds of catastrophes against which Wright warns.

To return to the original argument, students should certainly be exposed to the idea of progress first because it is indeed old (not old-fashioned) and being old has influenced crucial moments in civilization. Second, precisely because there has been such a reaction against (what is considered) an uncritical belief in progress, students are served very well by understanding what the debate is about and why it affects them and the ways that they face their futures.

Let us now take a step back and provide a definition this contested "idea of progress," something necessary for the discussion to proceed at all. Progress, as I understand it, means more than a sense that things have gotten better. Defining the term that broadly makes it impossible to distinguish what is characteristic of the idea of progress, namely that contained with history or society there is a kind of logic that leads to further forward developments. What does this "logic" mean?The best way to answer this is to contrast it with other, less scrupulous, definitions of the term. For instance, back in 1922 an American sociologist, George S. Painter was able to write, "The idea of progress arose at the very dawn of human thought. Its grounds are found both in the nature of experience and of the thinking mind." 8 In a strict sense, this statement is certainly wrong. Even if we make the unhistorical concession to allow the "dawn of human thought" to begin with the Greeks, as Painter seems to suggest, it is not true that early Greek writers like Homer gave much, if any, thought to the idea of progress. And

\footnotetext{
5 W. Warren Wagar, Good Tidings: The Belief in Progress from Darwin to Marcuse , p. 14.

6 Wright, p. 4.

7 Wright, p. 4.

8 George S. Painter, "The Idea of Progress," The American Journal of Sociology, Vol. XXVIII, Nov. 1922.
} 
while may in fact be the case that human mind is "wired" to compare (perceived) better and worse options, and thus draw conclusions about where things are heading, it is obviously not the case that the idea of progress - in the sense that it is most meaningful to use it-is suggested to us by nature, human nature included. Instead, it is suggested to us by civilization, and that is why it is so linked to all our arts and sciences.

To put this more precisely, the idea of progress, which defined broadly, is, as Painter suggested, a very old one. Furthermore, it isitself an elaboration or epiphenomenal on an already existing sense of history. This is a sense that has developed only occasionallyand in different forms-across human communities. This historical sense, whatever shape it takes, allows people to see existing institutions as the culmination of efforts have come before. This, in turn, allows people to envision directing, or perhaps simply observing, a coherent set of improvements on top of what came before. This mentality allows people to see in the world a "logic of dynamic development," even if this "logic" is not particularly complex (or even true), and even if what is understood as developing is not material forms, but a complex of aptitudes and theories. Seen this way, there is no single origin to either the sense of history, or of its channeling into an idea of progress.

For instance, in the Western world, various efforts to inculcate a sense of history also resulted in the creation of certain ideas of progress. For instance, a noted ancient historian, Polybius (c.200-118 BC) believed that the rise of the Roman Republic to world power was the greatest event (in his view) that history had seen. For this reason he had to develop theories about how history can progress forward, even if - in the end-he developed ideas of history that are much different than those in use today. What is true of the individual is also, in this case true of the collective: a civilization's sense of progress is inseparable from its idea of history.

Where does this leave us? It leaves us with, ultimately, is the argument that disciplines like archaeology are inextricably bound up with a sense of history, and that history itself is inextricably bound up with some notion of development, and thus something that will be related to the idea of progress. The French historian, Alain Schnapp, in his interesting volume The Discovery of the Past: The Origins of Archaeology provides ample evidence that long before there was a distinct science of archaeology, civilizations both East and West were curious about the origins of "the arts and of techniques." An example of this curiosity is reflected in a statement attributed to FengHuzi (c. 500 BC), a philosopher and expert in swords and antiquities:

In the time of Xuanyuan, Shennong and Hexu, weapons were made of stone to cut trees and build houses, and they were buried with the dead... in the time of Huangdi, weapons were made of jade, to cut trees build houses and dig the earth... and were buried with the dead. In the time of $Y u$, weapons were made of bronze to build canals... and houses. In our times, weapons are made of iron. ${ }^{9}$ 
Reflections like this not only culminate in a demand for archaeology as we know it today, but they also have an internal logic in the direction of ideas. Does this change in the use of metals equal development? Is it development forward? Is this progress? The fact that this logic is not always spelled out or pursued systematically does not mean that the idea of progress is one of the fundamental notions grappled with by civilizations with a historical sense.

Putting it this way may seem like stating the obvious. However, this obvious is missed when we begin the discussion with "myths of progress," The "religion of progress" and so forth. I agree that flaws in the idea of progress, and criticism of it cannot be avoided, and I will come to that shortly. But beginning the discussion with critique, while neglecting the fundamental role it plays gets the discussion off on the wrong foot entirely.

Where does this leave us in relation to the students? Certainly not that they must immerse themselves inthe writings of Herbert Spencer or Polybius (to say nothing of FengHuxi). These are little-studied figures even in the West, and I don't recommend that University of Indonesia students learn about them any more than American students should memories the names of kings in different parts of Nusantara. However, they were writers with something to say on general idea of progress and its relationship to the sense of history. Now, to begin to defend my main contention, this is something I suggest University of Indonesia students should study and reflect upon. This is even more true if they are in a discipline like archeology that does not necessarily demand training in philosophy, or the history of ideas. The question, once again, is why.

Here, let us move away from abstract reflections in philosophy and turn to the concrete discipline of archeology itself. What do students need to learn? At first glance the answer seems to be "anything but philosophy." But before we go further with that line of thinking we should recognize that there is one practical issue with very profound philosophical implications that every current archaeology student must confront. This is the question of fakes, frauds and authenticity. From the very start of organized archaeology there have been figures like the hapless Professor Beringer of Würzburg, Germany who in 1726 triumphantly announced the discovery of wondrous antiquities, completely oblivious to the fact that local teenagers were playing a trick on him by planting fakes where they know he would dig. ${ }^{10}$ But technical knowledge alone will not prevent the modern day Professor Beringer's from being duped. While technical knowledge is certainly necessary, along with street-smart savvy, some understanding of what it means for something likely to be true, as opposed to possibly being true is necessary. This requires some sense of philosophy, even if the philosophy is embedded in another subject matter. Moreover, cases of conscious frauds are rarer than what is called "selection bias," where researchers deceive themselves into believing that ambiguous evidence is certain and

${ }^{10}$ This story and more can be read in C.W. Ceram's Gods, Graves and Scholars: The Story of Archaeology, p. 21. 
that tentative conclusions are established. Distinguishing the possible from the likely in that case requires an even more intensive training in philosophy.

If someone wonders what this point has to do with the idea of progress the answer is that it seems to me to be highly unlikely that an archaeologist can distinguish authentic from inauthentic unless they have some idea of historical development, i.e., what could have happened at this time, as opposed to that time. And, as already argued, while development is not the same as progress, once we begin thinking in terms of historical development, we begin asking about historical progress.

This linkage of philosophy and archaeology becomes even more relevant when we consider that archaeology does not just blend into history and the social sciences, but also the natural sciences. Even from an outside perspective it is easy to see the tilt toward natural science in discovering and interpreting the material artifacts of the distant past. And with good reason: ever more sophisticated chemical and biochemical analysis has opened more and more doors of archeological understanding, and no student today can neglect the natural sciences if they want to dig up material remains. Yet, simultaneously, an ever wider range of valuable sites, combined with a wider knowledge-base and an increasing sophistication in the knowledge of archaic languages doubles and re-doubles the amount of empirical knowledge that an archeology student must absorb and process.

None of this seems to point in the direction of thinking about progress, but the fact is that the more archeology becomes interwoven with other sciences, especially empirical ones the more philosophical thinking about the nature of progress is pedagogically helpful.

There are two fundamental reasons for this, both which make a similar point. The first is that the consilience, or coming together of disparate disciplinary knowledge is increasingly a reality in $21^{\text {st }}$-century academic pursuits. ${ }^{11}$ As the Wikipedia article on the concept of "consilience" pithily puts it:

Modern views understand that each branch of knowledge studies a subset of reality that depends on factors studied in other branches. Atomic physics underlies the workings of chemistry, which studies emergent properties that in turn are the basis of biology. Psychology can no longer be separated from the study of properties emergent from the interaction of neurons and synapses. Sociology. economics, and anthropology are each, in turn, studies of properties emergent from the interaction of countless individual humans. ${ }^{12}$

To be sure, we do not have to accept the word of an anonymous author on the internet, but what is written here is hardly controversial, and it takes no risks to assert that advances in archeology will, in turn, be bound up with advances in other sciences.

I want to provide a specific example of this. One of the most effective ways

\footnotetext{
${ }_{11}$ The idea of "consilience" has received its widest propagation in E. O. Wilson's book Consilience: The Unity of Knowledge (New York), 1998.

${ }^{12}$ Wikipedia, "consilience," http://en.wikipedia.org/wiki/Consilience.
} 
that historian Ian Morris in his book Why the West Rules-For Now is able to advance a convincing argument that the economy of the ancient Mediterranean in the first century CE was so much stronger than the economy in the same region eight centuries later was due to the sophisticated archeological analysis of things like shipwrecks and lead levels in the soil. ${ }^{13}$ (Put simply, if both of these indicators go down, the economy is not as productive). This matter is of specific interest to students of economic history, but the larger point is relevant to us all. Without the integration of natural science into archeology and archeology into historical and economic analysis Morris could not have made his point at all. In fact, Professor Morris (1960-), now at Stanford University, is a good example is a good example of what we are talking about, since he is simultaneously a historian and an archaeologist, with strong attendant interests in a wide range of social and natural sciences. The ambitious work he is doing now could not be done if archaeology was not granted a significant role in understanding historical development. Students should be aware of this, and of the increasingly important role that multidisciplinarity plays in asking big questions.

For the current generation of students, therefore, consilience is here to stay. The question now is whether reflection on the idea of progress is needed to make sense of this ever-strengthening consilience. I think that it is. First, the very effort to forge links between different intellectual disciplines presupposes some understanding of the history of these different disciplines, even if it is an intuitive understanding. For this reason, bringing together different intellectual disciplines is always an effort to overcome perceived limitations. All this sounds very abstract, but it has a direct application. If archeologists cannot thinking about their own discipline without thinking about how relates to their disciplines, then they also cannot think about archeology without thinking about how scientific disciplines as a whole are getting better. This requires some training in thinking about the idea of progress.

A similar point could be made from the direction of the humanities and some of the social sciences. It may be the case that the humanities never admits of the kind of consilience that the natural sciences can obtain because the lack of empirical precision inherent in the disciplines precludes clear conclusions about what, exactly, is being combined. Nevertheless, even the most casual external observer can see that the integration of archeology with other fields places an increasingly "heavy" moral and interpretative burden on archaeologists. What do material remains reveal about the degree of oppression in a given society? What role does archaeology play in legitimating or challenging political ideologies today? These are questions anyone wishing to dig up the past and present it to the public must confront. But now is the time to press the point truly: what is it about

${ }_{13}$ Ian Morris, Why the West Rules - For Now: The Patterns of History and What They Reveal About the Future (New York), 2010, p. 288-309. 
the idea of progress that contributes so much to the education on the students? After all, a critic could accept the importance of the idea of progress, but still say that the defense I have given so far does not take sufficient account of three major drawbacks:

1. That endorsing progress creates an optimism so misguided that it only results in a foolish complacency about the future. Ronald Wright, the critic of progress quoted earlier, put this point dramatically when he suggest that humanity could be "doomed by hope" since "Hope drives us to invent new fixes for old messes which in turn create ever more dangerous messes." 14

2. As a corollary to the first point, endorsing progress not only makes about the future, but about injustices in the present and past as well, since oppression and suffering can be dismissed with the airy excuse that this was just the cost of moving forward.

3. Finally, even if it is conceded that ideas of progress do not invariably result in this kind of complacency, there is another kind arrogance that enthusiasm may engender.It is that progress will inculcate a narrow, tunnel vision, meaning that only the achievements of modern, Western societies are valued, and everything else is dismissed. This fear is summed up by a quote, widely spread on the internet, by Claude Levi-Strauss:"Enthusiastic partisans of the idea of progress are in danger of failing to recognize - because they set so little store by them - the immense riches accumulated by the human race on either side of the narrow furrow on which they keep their eyes fixed; by underrating the achievements of the past, they devalue all those which still remain to be accomplished."15

I will respond to all three of these criticisms shortly. For now, it suffices to that that there is a large difference between educating students about the idea of progress, and indoctrinating them to support it no matter what considerations speak against it. As I see it, the key problems found in the three points above come from ignoring evidence, rather than endorsing progress. To give some idea of why thinking about the idea of progress will, in fact, make it more likely why students will consider a broad range of evidence, I want to conclude by returning to the history of idea and offering three reasons why the students' future can be improved by further reflection on progress.

First, there is no better way to encourage students to see their own discipline from a variety of angles than to ask them to consider different varieties of progress in relation to their own subject matter. For instance, an archeology student must consider several questions of possible advance. She or he must ask to what extent an undeniable improvement in, say, methods of chemical analysis constitutes an undeniable

\footnotetext{
${ }_{14}$ Wright, p. 177.

15 See "Wikiquote" for Claude Levi-Strauss. The original can be found in Chapter 38 of his 1955 TristesTropiques.
} 
improvement in the analysis of ancient civilizations. Likewise, these students must also ask whether the presence or absence of innovation in constructing tools, builds, weapons, etc. does or does not result in something they would call progress or decline within the civilization itself. Finally, the very activity of looking at the distant past does in its own way call up the question of how human life currently is better or worse. Even if archeology students do not ask themselves such philosophical questions at any great length and with any great rigor, the very fact that they spent some time doing so can and I believe will help them think more carefully about their everyday practice.

Suppose that students, considering all this, do, in fact, decide to endorse some form of progress? Why is this a "belief" in the sense that religions have beliefs? Why would it engender a longing for a quick fix for today's problems, or a callous disregard for all who have suffered in the past? The answer to these questions is not forthcoming because the critics of the idea of progress simply assume it will come, rather than demonstrate that it will. In fact, if we want to guard against complacency asking students to reflect self-consciously on their enthusiasm for it (if they have it) and defend their choices rationally is one of the best protections that we have.

Second, since the end of the $19^{\text {th }}$ century criticisms of the idea of progress have obtained wide prominence in intellectual life. These criticisms take on any number of forms and opposition to the concept of progress has the capacity to unite otherwise implacable opposed schools of thought. ${ }^{16}$ Conservatives who believe that progress undermines valuable traditions have something in common with progressives who think that ideologies of progress are used to justify and rationalize away western domination of less-developed societies. Given this wide range of views, there is no point in trying to decide if critiques of progress are right or wrong, since they vary widely in quality and form. Nevertheless, there is one quality that criticisms of the idea of progress tend to share, namely a hostility to the claim to rationality. This hostility can be expressed by religious believers and romantics who find the scientific advance of society "alienating" to thorough-going rationalists like Karl Popper who endorsed progress, but who rejected pseudo-scientific claims to automatic progress contained in "historicism."17

Now, the question to be asked is whether archeology students are truly better off if they are exposed to some form of anti-rationalism, either through direct instruction, or simply through the intellectual climate. Consider one more quote from Ronald Wright:

\footnotetext{
${ }^{16}$ General background on this topic is found in Robert A. Nisbet'sHistory of the Idea of Progress (New York), 1980. Summarizing a central aspect of Nisbet's account Robert Welker explained: “Nisbet's argument is that the inflated pretentions of social science led to heightened cultural expectations that were unreachable. When the expectations were not fulfilled, rational knowledge itself was called into question." Quoted from The Teacher as Expert: A Theoretical and Historical Examination (SUNY Series in Teacher Preparation and Development, 1990).

17 See Karl Popper's The Open Society and its Enemies, Vol. I \& II, rev. ed. (Princeton), 1950.
} 
Those who traveled in their youth and have gone back to old haunts after twenty or thirty years can't fail to observe the massive onslaught of progress, whether it be the loss of farms to suburbs, jungles to cattle ranchers, rivers to dams, mangroves to shrimp farms, or coral reefs to condominiums.

After noting the unification of the world's economic system, Wright adds:

The twentyfold growth in world trade since the 1970's has meant that hardly anywhere is selfsufficient. Every Eldorado has been looted, every Shangri-La equipped with a Holiday Inn. ${ }^{18}$

Wright's concern is that contemporary civilization not destroy itself in a collapse similar to those undoing civilizations of the past. There is nothing objectionable in this, but critics of progress hold no monopoly on this concern, and it distorts the image of progress to associate it exclusively with things that you, personally, happen to dislike. Consider this statement from the perspective of a student today who has not had a chance to travel in their youth. Where would they be without the economic growth of the last forty years? This question must be considered, and plans made to help them even if one sees nothing but "looting" in economic growth. Moreover, if today's students truly are to address the problems of the "system" they should not be taught the kind of arrogance that allows them to neatly split the world into two opposing camps, one good and the other bad. This is what I understand the critics of progress to be doing. Yet human progress has always had ambiguous results, creating new problems as it solves old ones. What we need more than ever today is a generation that does not think in dualistic categories, presuming that those who are short-sighted and misguided are entirely on one side and those who think "long-term" are entirely on the other. We also do badly if we educate students to idealize "Shangra-La's" of the past, while depreciating efforts toward the even greater progress that comes from trying to solve the problems that previous progress has created.

That is all well and good, but do archaeology students at The University of Indonesia really need to think about it? Will time spent on such an abstract and complicated matter bring students some tangible benefit in their education? My answer is yes. In an age of globalization, where students must contend with rapidly changing markets and many levels of competition it may look like all this is asking students to distract themselves from their main tasks. However, I feel that the opposite is true. Thinking about progress does not distract from practical considerations. In fact, it intensifies them, and it does so in a very helpful way. The reason why this is so can be stated bluntly: when students are asked to think about whether humanity is moving forward and how, specifically, it is doing so, it makes it easier for the instructor to ask the students a very pointed and very necessary question, namely whether they themselves are moving forward and how they are doing so.

This pointed question is very necessary for students across the world, including

\footnotetext{
${ }^{18}$ Wright, p. 178.
} 
Indonesia. A student that does well on exams and follows the professor's lead in learning is much better than a student who does neither. But in the globalized world this is not enough. To be successful a student cannot think passively, and ways must be found to help them progress to thinking critically and actively. In the specific case of archaeology, thinking about the idea of progress helps them be less passive in understanding their subject's link to social and natural sciences, as well as the shared problems of contemporary life.

What I have suggested for students of archaeology could be adapted and tailored for students in practically all subjects and faculties. Reflection on progress can supply students with the perspective that they need in order to keep them moving forward, and individual departments can decide for themselves how to incorporate it into their curriculum. One of the principal challenges for a university student today is to have clear insight into their own "logic of development." They can do this better if they spend time thinking about development in a larger sense.

\section{PRINCIPAL WORKS CITED}

Ceram, C.W. Gods, Graves and Scholars: The Story of Archaeology. London: Phoenix Press. English edition 2001/1971, revised from 1952 original.

Iggers, George G. “The Idea of Progress: A Critical Reassessment,” American Historical Review, Vol. 71. 1965.

Morris, Ian. Why the West Rules - For Now: The Patterns of History and What They Reveal About the Future. New York: Picador. 2010.

Painter, George S. "The Idea of Progress," The American Journal of Sociology, Vol. XXVIII. 1922.

Schnapp, Alain. The Discovery of the Past, London: British Museum Press. English edition 1996, French original 1993.

Spencer, Herbert. "Progress its Laws and Causes," taken from the Internet History Sourcebook. Fordham University. 1857.

Wagar, W. Warren. Good Tidings: The Belief in Progress from Darwin to Marcuse. Bloomington, IN, University of Indiana Press. 1972.

Wright, Ronald. An Illustrated Short History of Progress. Toronto ON: Anasi Press. 2006. 